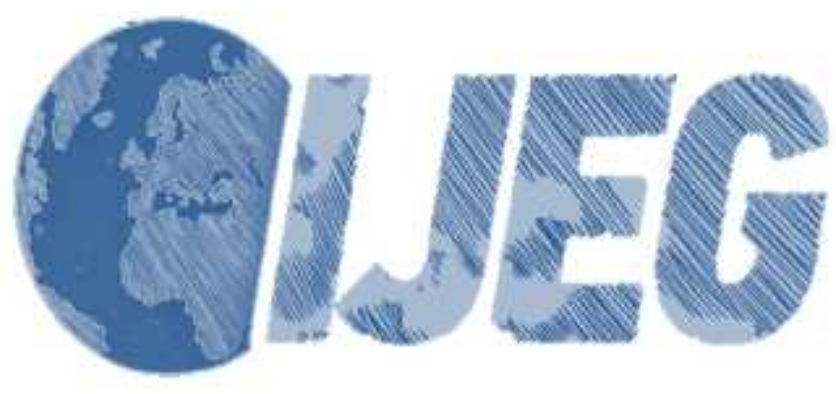

International Journal of Engineering and Geosciences (IJEG), Vol; 2; , Issue; 02, pp. 41-51, June, 2017, ISSN 2548-0960, Turkey, DOI: 10.26833/ijeg.297271

\title{
PREFERENCE CHANGES DEPENDING ON AGE GROUPS OF CRITERIA AFFECTING THE REAL ESTATE VALUE
}

\author{
Unel, F.B., ${ }^{1 *}$ Yalpir, S., ${ }^{1}$ and Gulnar, B., ${ }^{2}$ \\ ${ }^{1}$ Selcuk University, Engineering Faculty, Department of Geomatic Engineering, Konya, Turkey. \\ (fatmabunel@gmail.com; sarici@ selcuk.edu.tr); \\ ${ }^{2}$ Selcuk University, Communication Faculty, Department of Radio-Television and Film, Konya, Turkey. \\ (bgulnar@selcuk.edu.tr)
}

*Corresponding Author, Received: 10/03/2017, Accepted: 03/06/2017

\begin{abstract}
In this study, whether or not the criteria affecting plot value changes depending on age was investigated in Ankara, Konya and Kayseri, which are three major cities of The Central Anatolian Region in Turkey, through survey method. 2,531 respondents, who were 18 and older, were included in the survey based on a technical viewpoint. Respondents consisted of 559 experts and 1,915 citizens. Fifty seven survey forms were considered invalid for several reasons and excluded from evaluation. The experts were selected from among people who worked on real estate valuation by using The Purposeful Sampling Method. The citizens were chosen from among people who could as well be agents in purchase and sale of the real estate by using The Simple Random Sampling Method. The survey questions were prepared on a Five-Point Likert Scale. These were made up of a total 82 questions and two main titles as locational (64 criteria) and neighbourhood (18 criteria) features (except for demographic questions). The age of the respondents was classified into six different groups. Whether or not averages of criteria were significantly different depending on the age groups was tested by ANOVA. Differences between the age groups were determined through several criteria.
\end{abstract}

Keywords: Real Estate Valuation, Plot, Criteria, Survey, Age. 


\section{INTRODUCTION}

Real estate is patches or pieces of land essentially belonging to a country and reserved for public or private use. Real estates are used for shelter, trade, production and as public areas. Besides, they change the velocity of the economy through project designing, credit arrangement and tax imposing. Real estate valuation is the process of determining the purchase and sale value of real estates on the market under certain conditions for a certain period of time. The acceleration in global population and development has increased the variety and amount of the human requirements. Particularly with the growth in communication, logistics and transportation, a rapid change and progress is witnessed chiefly in trade. This commercial and social globalization has made real estate valuation more crucial. Therefore, the values of real estates are important and the reasons for the valuation of real estates in Europe and on a global scale are more or less the same; however, the tools and methods used in the process of valuation are not so (Köktürk 2009). The work of valuation is an extensive field of expertise which needs to be handled with its technical, economical and legal aspects (Açlar et al., 2003). Determination of the values of real estates accurately, objectively and reliably by experts is an issue on which all the countries dwell, particularly from an economical perspective.

The real estates valuable for national and international investors are parts of the economy. Acquisition of a real estate requires making crucial decisions in every aspect in a person's life for the purpose of shelter or trade in terms of personal and domestic economy. In parallel with global changes, the regulations concerning real estates may be faced with constant changes through reforms. For instance, imposing tax on urban rent and protection laws for agricultural fields are the most obvious among them. In addition, real estate certificate is also one of them so that the real estate can be divided into shares and it can be sold or bought easily. However, legislation that is coherent and strong in terms of sanctions is required for these purposes to be realized. The value given to the real estate in Turkey may sometimes not have any material equivalent. A spiritual value may be attached to some real estates inherited from ancestor(s) due to the past experiences. Historical and very special real estates in terms of their location are within these exceptions. Because they are not in consideration for sale, they are not valued for a price. But the values of the real estates must be known so that they can be taxed. Thus, a valuation process of real estates that is easily modeled transparently is required. A move in valuation from reality in terms of price/benefit would give rise to new problems. All these problems and uncertainties could as well lead to a new economic crisis in time.

The value of the real estates exhibits less change in countries with a stable economy. Further, they maintain their values in the face of inflation even in harsh economic conditions. Thus, the acquisition of a real estate has become more common both because of a necessity and with a view to investment. The increase in the need for real estates in the social and economic sense has brought out the credit system called mortgage. As the volume of the real estates has grown in the economy, their contribution to the economy in such aspects as credit and tax has also increased. Mortgage history has its roots in ancient civilizations. The rise of the United States' mortgage market occurred between 1949 and the turn of the $21^{\text {st }}$ century. The mortgage debt to income ratio rose from 20 to 73 percent during this time. However, the economic crisis that took place in 2008 because mortgage credits could not be paid back escalated into a Global Economic Crisis (Mortgage Calculator, 2016). Mortgage system was introduced into Turkey in 2007. A lot of regulations were made in the legislation concerning the system. It is necessary to establish the value of the real estate close to the actual value on the market in accordance with the legislation in order for other crises not to occur. Investment in real estate in Turkey has increased more with the mortgage system. Mortgage system has lowered average age of the real estate buyers. Before the mortgage system, the people with a low income could only buy a real estate after the retirement. After the mortgage system, the real estate ready for use is financed by banks and the repayment is arranged in installments to continue for years. Along with the mortgage system, people of all ages can now buy a real estate, which is prompted by an increase in the income level of the household. This makes it possible to learn the criteria people consider while buying a real estate for every age group.

The surveys conducted in the literature were generally conducted to value real estates and to rank the criteria after weighting them (Yomralığlu, 1993; Bender et al., 2000; Kryvobokov, 2005; Nişancı, 2005; Yalpir, 2007; Çakır and Sesli, 2013). A survey was carried out in several countries by The United Nations Economic Commission for Europe Working Party on Land Administration (UNECE WPLA) between 20002001 and 2011 (UNECE WPLA, 2001; 2014). In addition, there are studies based on specific criteria such as large urban parks (Hammer et al., 1974), traffic noise (El-Gohary, 2004; Szczepanska et al., 2015), air pollution (Ridker and Henning, 1967; Zheng et al., 2014), view value (Jim and Chen, 2009; Damigos and Anyfantis, 2011), stanbul Finance Center Project (Teker et al., 2012), shale gas (Lipscomb et al., 2012; Muehlenbachs et al., 2015) and zebra mussels (Henry, 2013). Hurma et al., 2012 determined criteria affecting the value of agricultural land. Also, there are applications with modern methods such as artificial intelligence in real estate valuation (Selim, 2009; Kuşan et al., 2010; Bulut et al., 2011; Yalpir et al., 2014). Yet, there are no studies that research whether the criteria for real estates changes with age groups of people.

In this study, plot was taken into account as a sort of real estate. The purpose of this study is to establish whether there are any significant differences in the criteria affecting the value of the plot depending on the age. Survey questions were asked to experts working on real estate valuation and to citizens interested in this field. The age, one of the demographic questions, was asked as an open-ended question. Age factor was grouped as "no answer", "18-29", “30-39", “40-49", "50-59" and "60+". The criteria affecting the value of the plot were grouped into two main titles that are locational and neighbourhood features. ANOVA analysis test was used to see if there were any significant 
differences between the averages (av.) of the criteria according to the age groups.

\section{MATERIAL AND METHODS}

\subsection{Study Areas}

It is investigated by taking into account population, the number of voters, population increase speed and net speed of migration, the number of sales, housing mortgage and the number of processes in zoning applications relative to all city located in the Central Anatolian Region. For this reason, Ankara, Konya and Kayseri are determined as study areas (Figure 1).

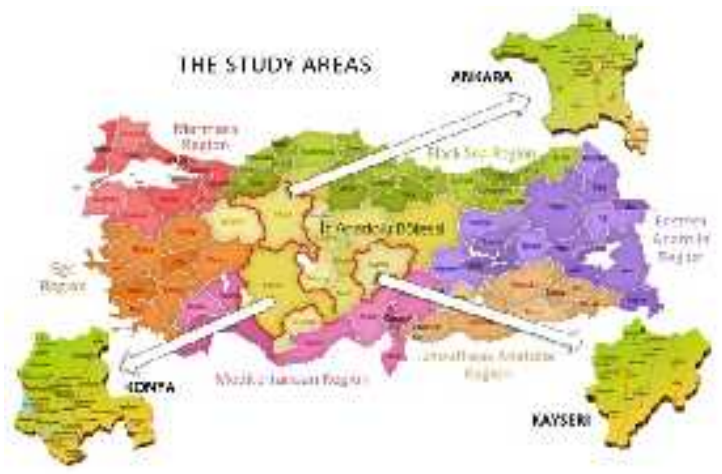

Figure 1. Study areas

\subsection{Plot}

In a general sense, real estates vary, depending on the purpose of use. In Turkey, they are classified as plot, land and building (Real Estate Tax Law, 1970, Article 112). The buildings are further divided into housing (buildings in residential areas), commercial (Shopping Centers, restaurants, etc.), public buildings (schools, hospitals, etc.) and industrial buildings (factories, thermal power plants, etc.) (Yomralığlu, 1997; Yalpir, 2007; USPAP, 2013). Zoning parcel, defined as plot, is the form of cadastral parcels designed according to the Zoning Law, the zoning plan and directives (Zoning Law, 1985, Article 5).

For this reason, licensed buildings can only be constructed on the real estate qualified as a plot. However, for the purpose of shelter, multi-storey $(>2)$ and licensed buildings cannot be constructed on the land. The real estates used for agricultural purposes, such as fields, vineyards and orchards, are defined as land. This important distinction between plot and land is also reflected on their economical value.

\subsection{The Criteria Affecting the Value of the Plot}

The criteria affecting the value of the plot were laid down after the directives related to real estate evaluation and academic studies were examined. The literature contains post-graduate/doctorate theses, national and international papers, international standards, reports by valuation experts and valuators, laws, regulations, circulars and notifications. The criteria affecting the value of a real estate are sorted as locational, neighbourhood, legal and physical ones. In this study, the choices regarding the criteria, which are under two main titles, "locational features" and "neighbourhood features" were examined in accordance with the age distribution.

Locational features involve social facilities that could be present around the plot (especially walking distance). These are composed of the subtitles of healthcare organizations, educational institutions, public agencies and security units, attraction, shopping, cultural and entertainment centers, green areas, transportation networks, insanitary areas, industrial areas, cemeteries, worship places, business centers, parking areas and view. Neighbourhood features constitute the situation of the neighbourhood in which the plot is located. These are given under the subtitles of population, environmental perspective of the neighbourhood and underground, ground, over-ground features. Under most of the subtitles are the criteria (Figure 2). Survey questions were formed with the arrangement of this hierarchical structure.

Survey questions were prepared through five-point Likert Scale (Table 1). Five-point Likert Scale was arranged as not important (1), a little important (2), moderately important (3), important (4) and very important (5). The criteria have increasing/decreasing effects on the value of the plot. Therefore, the positive effect (+) and the negative effect (-) were also added to the survey questions. The respondents were asked to answer the questions by considering the effects of the criteria on the value of the plot and comparing them with each other. Demographic questions are related to the place of residence, the age, the gender, the level of education and the job. Of them, we considered the feature of age and studied whether there was a significant difference between the average values of the criteria.

Table 1 Explanations Survey Questions

\begin{tabular}{|l|c|c|}
\hline \multicolumn{1}{|c|}{$\begin{array}{c}\text { Question } \\
\text { Group }\end{array}$} & $\begin{array}{c}\text { Question } \\
\text { Type }\end{array}$ & The Scale \\
\hline $\begin{array}{l}\text { Locational } \\
\text { Features }\end{array}$ & $\begin{array}{c}\text { Open-ended } \\
\text { questions }\end{array}$ & $\begin{array}{c}\text { Five-point likert } \\
\text { scale }\end{array}$ \\
\hline $\begin{array}{l}\text { Neighbourhood } \\
\text { Features }\end{array}$ & $\begin{array}{c}\text { Open-ended } \\
\text { questions }\end{array}$ & $\begin{array}{c}\text { Five-point likert } \\
\text { scale }\end{array}$ \\
\hline $\begin{array}{l}\text { General } \\
\text { Situation }\end{array}$ & $\begin{array}{c}\text { Open-ended } \\
\text { questions }\end{array}$ & $\begin{array}{c}\text { The total-fixed } \\
\text { scale }\end{array}$ \\
\hline $\begin{array}{l}\text { Demographic } \\
\text { Questions }\end{array}$ & $\begin{array}{c}\text { Open- and } \\
\text { closed-ended } \\
\text { questions }\end{array}$ & $\begin{array}{c}\text { A mixed scale } \\
\text { (multiple choice, } \\
\text { script writing, etc.) }\end{array}$ \\
\hline
\end{tabular}

Based on this situation, Null $\left(\mathrm{H}_{0}\right)$ and alternative $\left(\mathrm{H}_{\mathrm{A}}\right)$ hypotheses were formed as follows:

$\mathrm{H}_{0}=$ There are no differences between the average values belonging to age groups.

$\mathrm{H}_{\mathrm{A}}=$ There is a difference between the average values belonging to at least two age groups.

\subsection{One Way Variance Analysis (ANOVA)}

In practice, the test required to study the differences and to compare more than two groups is one way variance analysis (Analysis of Variance-ANOVA) (Altunışık et al., 2010). ANOVA is the process of testing whether the difference between two or more related samples is significantly different from null in any way. 
The following assumptions must be fulfilled for this analysis to be conducted (Gulnar, 2007):
1. The measuring level of the dependent variable must be at the least spacing scale.

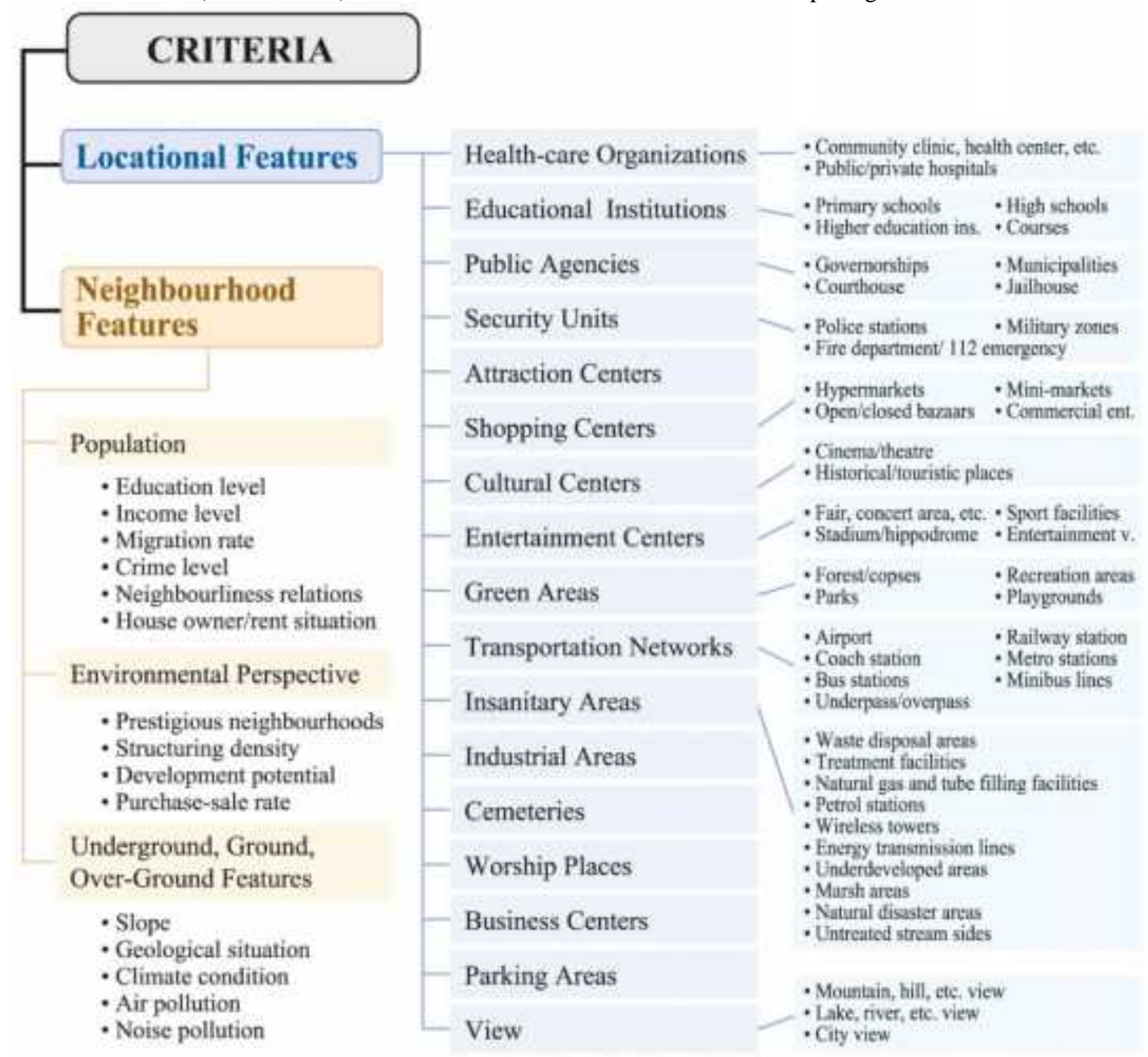

Figure 2. The Subtitles of Locational and Neighbourhood Feature and the Criteria

2. The points are normally distributed at each level of the factor whose effect on the dependent variable is studied.

3. The samples for which points of average will be compared are unrelated.

4. Variances of the samples are equal.

The fact that the significance level in ANOVA test ( $F$ test) is under 0.05 suggests that there are differences between the groups. If otherwise, there are no differences between them (Altunışık et al., 2010). When there is a difference, "Post Hoc Multiple Comparative Methods" are used to determine in which group there is a difference. Post Hoc Comparative Methods, which vary depending on whether variances are equal or not are as follows (Kayri, 2009; IBM, 2015):

When variances are equal,

- $\quad$ Spaced and binary tests (Tukey, Hochberg's GT2, Gabriel and Scheffe)

- $\quad$ Spaced tests (Tukey's b, S-N-K (StudentNewman-Keuls), Duncan, R-E-G-W-F (Ryan-EinotGabriel-Welsch F test), R-E-G-W-Q (Ryan-EinotGabriel-Welsch range test) and Waller-Duncan)
- Binary tests (Bonferroni, Tukey, Sidak, Gabriel, Hochberg's GT2, Dunnett, Scheffe and LSD (Least Significant Difference)) are used.

When variances are not equal,

- Multiple Spaced tests (Tamhane's T2, Dunnet's T3, Games-Howell and Dunnet's C) are used.

In this study, Bonferroni test was preferred when variances were equal, and Tamhane's T2 method was preferred when variances were not equal, as they are easy to apply and use in multiple comparison tests (Doğan and Doğan 2014). Also, when the sample groups were not equal, the methods of Bonferroni (Psych Colorado 2015) and Tamhane's T2 were employed (Kayri, 2009).

\section{APPLICATION}

\subsection{Determination of the Study Field and Sample} Size

It is a prerequisite to determine the cities to be considered main-mass. For this reason, the cities in the Central Anatolian Region were examined in terms of population and the level of development. In terms of 
population, such factors as population, the number of voters, population increase speed and net speed of migration were taken into account, while the number of sales, housing mortgage and the number of processes in zoning applications were considered in terms of development.

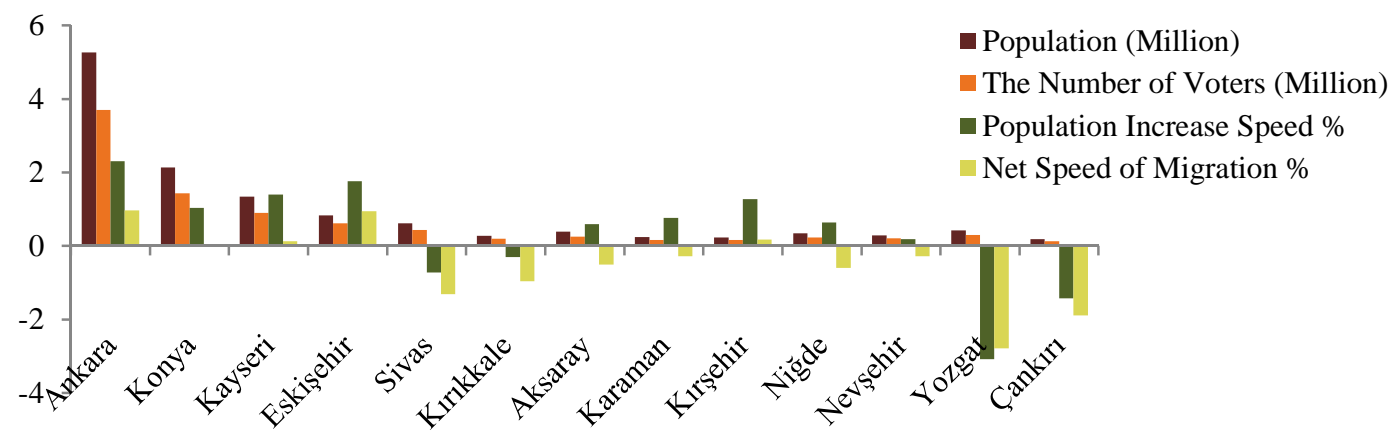

Figure 3. Graphical Demonstration of Population, the Number of Voters, Population Increase Speed and Net Speed of Migration (TUIK, 2015; YSK, 2015).

The data were obtained from the Turkish Statistical Institution (TUIK), the Supreme Election Board (YSK) and the General Directorate of Land Registry and Cadastre (TKGM). The cities of Ankara, Konya and Kayseri had the highest population and the highest the number of voters. It was revealed in Figure 3 that there were generally positive increases in Ankara, Eskişehir, Kırşehir, Kayseri and Konya. Figure 4 shows that the number of purchase and sale transactions was generally more in Ankara, Konya and Kayseri than in the other cities. Plots should be produced in places where there is a lot of population because of the shelter need. Figure 3 and Figure 4 clearly show cities where there are especially lots of population and zoning applications. For these reasons, Ankara, Konya and Kayseri were decided on as the area of the study.

As regards valuation, samples were taken from public institutions, professional organizations and private sector which were within the scope of the study. Real estate valuation concerns a number of professional groups since it is a much disciplined issue. These groups are made up of experts working on valuation, valuation specialists, valuators, constructors, real estate agents and the units that are dealt with in the literature.

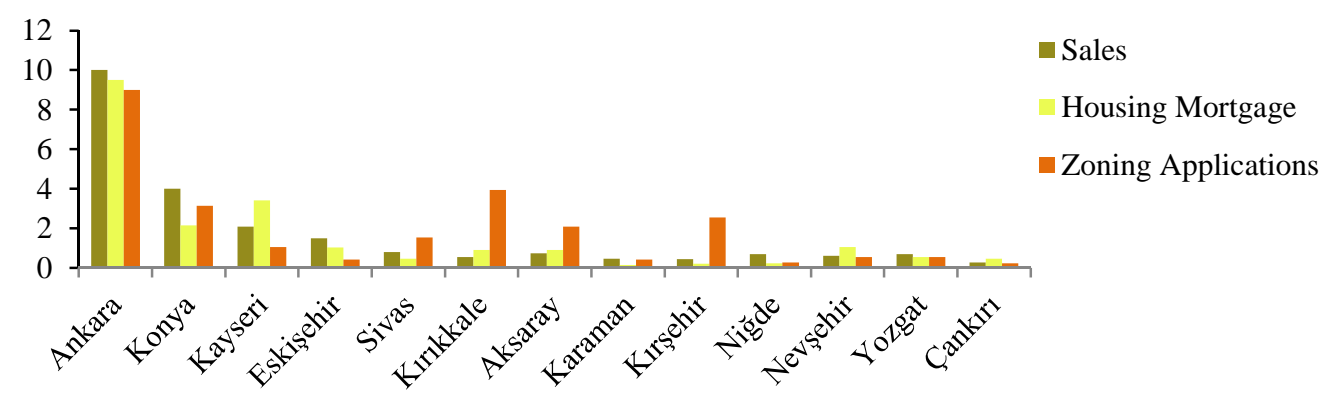

Figure 4. The Distribution of Real Estate Sales, Housing Mortgage and Zoning Applications in the Cities in the Central Anatolian Region (TKGM, 2015), (The original numbers were pulled into the spaces between 0 and 10).

The branches of professions are the branches of geometrics engineering, real estate and asset valuation, city and regional planning, agricultural engineering, civil engineering, architecture, economic and administrative sciences and the law. The majority of those in the citizen group were personally involved in buying and selling real estates. The respondents are made up of two main groups, "experts" and "citizens" (Figure 5).

$5 \%$ for margin of error and $95 \%$ confidence interval were taken into consideration while calculating the size of samples. Experts were chosen through the purposeful sampling method, and citizens were chosen via the simple random sampling method. Experts were limited in number, and the total number of samples was 375 . Public institutions were universities, TKGM, municipalities and other agencies and associations, with a sample number of 57. Professional organizations were the Turkish Union of Valuation Experts, the Association of Valuation Experts, and the Union of Licensed Valuation Companies, with a sample number of 5. 


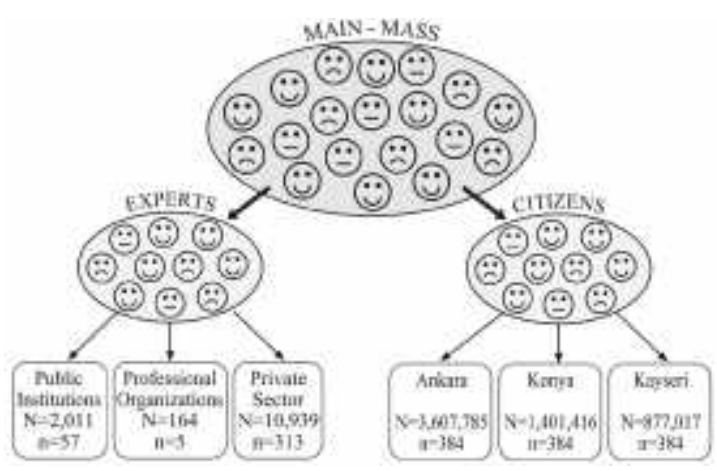

Figure 5. Main-mass of the Respondents and the Number of Samples

The private sector was composed of valuation experts employed in valuation firms, constructors and real estate agents, with a sample number of 313. As citizens, the number of voters in Ankara, Konya and Kayseri was $3,607,785 ; 1,401,416$ and 877,017 (YSK, 2015) respectively with a sample number of 384 for each city (Figure 5). The number of experts was planned to be 500 experts and 2,000 citizens as a precaution against such setbacks as missing information in the survey forms and repetition of the same answers. Fifty seven survey forms were considered invalid for several reasons and thus excluded from evaluation. As a result, survey questions were answered by 559 respondents and 1,915 citizens (Table 2).

\subsection{Classification of Ages}

Age can be defined through biological and chronological criteria. World Health Organization defines the age of 60 and over as old and 80 and over as very old. Differing classifications are also suggested as a criterion for chronological aging. For instance, 45-59 is defined as middle age, 60-74 as old, 75 and over as elderly and 90 and overt very elderly (Turaman, 2001; 22-27). Several age classifications have been made by TUIK. One of these is to define $0-14$ as young age, 1564 as middle age and $65+$ as old age in the population data by years, age group and sex. This study divides ages into "no answer”, “18-29”, “30-39”, “40-49”, “5059 " and " $60+$ ", because the transactions of purchase and sales start at the age of 18 .

Table 2 The Survey Data

\begin{tabular}{|l|c|c|}
\hline The Survey Data & Experts & Citizens \\
\hline Sampling Areas & Ankara, Konya and Kayseri & Ankara, Konya and Kayseri \\
\hline Sampling Method & The Purposeful Sampling & The Simple Random Sampling \\
\hline Respondents & $\begin{array}{c}\text { Public institutions, professional } \\
\text { organizations and private sector }\end{array}$ & $\begin{array}{c}\text { Citizens that may take role in buying } \\
\text { and selling of real estates }\end{array}$ \\
\hline Main-Mass Number & $2,011+164+10,939=13,114$ & $3,607,785+1,401,416+877,017$ \\
\hline Sample Number & $57+5+313=375$ & $384 * 3=1,152$ \\
\hline Data Types & The Survey questions & The Survey questions \\
\hline Data & The Survey data & The Survey data \\
\hline
\end{tabular}

The choices of purchase and sales vary with their incomes and social status. $1 \%$ in no answer category that did not give any answers to the age question was disregarded. It is seen that the 30-39 age group had the highest number of respondents, with $32 \%$ (Figure 6).

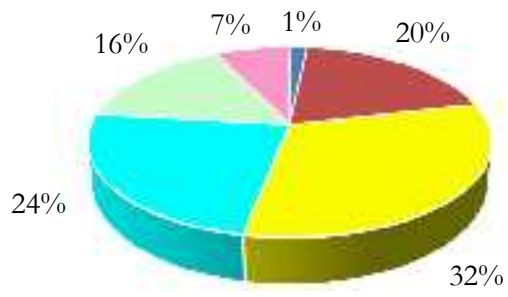

- No Answer = 18-29 = 30-39 | 40-49 =50-59 =60+

Figure 6. The Percentages of the Respondents by Age Groups
The process of aging differs in differing countries depending on nutrition, working and living conditions. It is understood from the statistics by the Turkish Statistical Institution that the number of young population is bigger than that of old population. Also, the number of old and elderly people is decreasing as life expectancy is short. The Organization for Economic Cooperation and Development (OECD) published life expectancy figures for countries in 2015. According to these figures, health spending in Turkey is under 1000 dollars per person and life expectancy is seen to remain under 77 years (OECD, 2015). Age classification was terminated with the category of $60+$ as there were few respondents over 70 participating in the study.

\subsection{Comparison of the Criteria Affecting the Plot Value by Age}

The criteria affecting the plot value were made up of 82 questions, 64 about locational features and 18 about neighbourhood features. The average values of these questions by age groups were taken. ANOVA was used to see whether there were differences between the average values. All of the experts and citizens in the 
three cities were put through analysis at the same time. ANOVA results were assessed at the significance level of 0.05 . As a result of this analysis, it was established that there was not a significant difference between the average values of the criteria by age groups as seen below:

- $\quad$ Military zones $(\mathrm{F}=1.778 / \mathrm{p}>.05)$,

- Underpass/overpass $(\mathrm{F}=2.187 / \mathrm{p}>.05)$,

- Industrial Areas $(\mathrm{F}=1.557 / \mathrm{p}>.05)$,

- $\quad$ Parking Areas $(\mathrm{F}=2.217 / \mathrm{p}>.05)$,

- Population $(\mathrm{F}=0.397 / \mathrm{p}>.05)$,

- Migration rate $(\mathrm{F}=1.502 / \mathrm{p}>.05)$,

- $\quad$ Structuring density $(\mathrm{F}=1.503 / \mathrm{p}>.05)$

- $\quad$ Slope $(\mathrm{F}=1.019 / \mathrm{p}>.05)$

Bonferroni and Tamhane methods were used to reveal whether there were any differences between the age groups in terms of the other criteria.

The criteria of higher education institutions, Public Agencies, governorships, municipalities, Security Units, police stations, hypermarkets, mini-markets, open/closed bazaars, commercial enterprises, coach station, a mountain, hill, etc. view, income level, purchase-sale rate and geological situation had equal variances (p>.05), which was the result of Bonferroni method. Yet, no significant difference was found between the age groups.

For the criteria whose variances were not equal $(\mathrm{p}<.05)$, Tamhane method was used and the results are as follows:

- Community clinic, health center, etc. $(\mathrm{F}=12.072 / \mathrm{p}<.001)$

- Courthouse $(\mathrm{F}=4.721 / \mathrm{p}<.001)$,

- Jailhouse ( $\mathrm{F}=4.986 / \mathrm{p}<.001)$,

- Cinema/Theatre $(\mathrm{F}=6.164 / \mathrm{p}<.001)$,

- Historical/touristic places $(\mathrm{F}=5.674 / \mathrm{p}<.001)$,

- Entertainment Centers ( $\mathrm{F}=12.105 / \mathrm{p}<.001)$,

- Fair, concert area, etc. $(\mathrm{F}=7.530 / \mathrm{p}<.001)$,

- Sport facilities $(\mathrm{F}=8.198 / \mathrm{p}<.001)$,

- Stadium/hippodrome $(\mathrm{F}=6.619 / \mathrm{p}<.001)$,

- Entertainment venues $(\mathrm{F}=7.984 / \mathrm{p}<.001)$,

- Green Areas $(\mathrm{F}=13.559 / \mathrm{p}<.001)$,

- Forest/copses ( $\mathrm{F}=9.156 / \mathrm{p}<.001)$,

- Recreation areas $(\mathrm{F}=5.481 / \mathrm{p}<.001)$,

- Parks ( $\mathrm{F}=7.281 / \mathrm{p}<.001)$,

- Airport $(\mathrm{F}=4.633 / \mathrm{p}<.001)$,

- Insanitary Areas $(\mathrm{F}=8.452 / \mathrm{p}<.001)$,

- Waste disposal areas ( $\mathrm{F}=9.858 / \mathrm{p}<.001)$,

- Treatment facilities $(\mathrm{F}=10.911 / \mathrm{p}<.001)$,

- Natural gas and tube filling facilities $(\mathrm{F}=11.431 / \mathrm{p}<.001)$,

- Petrol stations $(\mathrm{F}=11.470 / \mathrm{p}<.001)$,

- Wireless towers $(\mathrm{F}=11.849 / \mathrm{p}<.001)$,

- Energy transmission lines $(\mathrm{F}=12.326 / \mathrm{p}<.001)$,

- Underdeveloped areas $(\mathrm{F}=8.692 / \mathrm{p}<.001)$,

- Marsh areas ( $\mathrm{F}=11.425 / \mathrm{p}<.001)$,

- Natural disaster areas $(\mathrm{F}=11.470 / \mathrm{p}<.001)$,

- Untreated stream sides $(\mathrm{F}=13.259 / \mathrm{p}<.001)$,

- Worship Places $(\mathrm{F}=7.174 / \mathrm{p}<.001)$,

- Education level $(\mathrm{F}=10.884 / \mathrm{p}<.001)$,

- Neighbourliness relations $(\mathrm{F}=11.565 / \mathrm{p}<.001)$,

- House owner/rent situation ( $\mathrm{F}=4.771 / \mathrm{p}<.001)$,

- Climate condition ( $\mathrm{F}=3.627 / \mathrm{p}<.01)$,

- Air pollution $(\mathrm{F}=7.893 / \mathrm{p}<.001)$ and
- Noise pollution $(\mathrm{F}=8.004 / \mathrm{p}<.001)$.

Null hypothesis was rejected for the 33 criteria here. That is, it was established that there was a significant difference between the average values of the age groups as regards these 33 criteria. Which age group(s) paid attention to the 33 criteria was studied and the following results were found:

- Community clinic, health center, etc. was significantly more important for "60+" (av.=4.11) age group than for "18-29" (av.=3.72) age group,

- Courthouse was significantly more important for "30-39" (av.=1.93) age group than for "50-59" age group (av.=1.32),

- Jailhouse was significantly more important for "4049 " (av.= -2.41) and "50-59" (av.= -2.59) age groups than for "18-29" (av.=-1.76) age group,

- Cinema/Theatre was significantly more important for "18-29" (av.=2.88) age group than for "50-59" (av.=2.40) age group,

- Historical/touristic places was significantly more important for "18-29" (av.=2.79) age group than for "50-59" (av.=2.17) age group,

- Entertainment Centers was significantly more important for "18-29" (av.=2.71) and "30-39" (av.=2.49) age groups than for "40-49" (av.=1.97), "50-59" (av.=1.89) and "60+" (av.=1.62) age groups,

- Fair, concert area, etc. was significantly more important for "18-29" (av.=2.21) and "30-39" $(a v .=2.23)$ age groups than for "40-49" (av.=1.72) and "50-59" (av.=1.56) age groups,

- Sport facilities was significantly more important for "18-29" (av.=2.75) age group than for "30-39" $(\mathrm{av} .=2.81)$ age group, "50-59" (av.=2.32) and "60+" (av.=1.84) age groups,

- Stadium/hippodrome was significantly more important for "18-29" (av.=1.99) age group, "40-49" (av.=1.43) and "50-59" (av.=1.21) age group and also for "30-39" (av.=1.89) age group than for " 50 $59 "($ av.=1.21) age group,

- Entertainment venues was significantly more important for "18-29" (av.=2.26) and for "30-39" (av.=1.98) age groups than for "50-59" (av.=1.41) and "60+" (av.=1.17) age groups as well as for "18$29 ”$ (av.=2.26) age group , “40-49” (av.=1.58) age groups,

- Green Areas was significantly more important for "60+" (av.=4.00) age group than for "18-29" $(a v .=3.41), \quad " 40-49 " \quad(a v .=3.63)$ and "50-59" (av.=3.55) age groups,

- Forest/copses was significantly more important for "60+" (av.=3.68) and "40-49" (av.=3.32) age groups than for "18-29" (av.=2.92) age group,

- Recreation areas was significantly more important for "60+" (av.=3.38) age group than for "50-59" (av.=2.64) age group,

- Parks was significantly more important for "60+" (av.=3.75) age group than for "18-29" (av.=3.30) age group,

- Airport was significantly more important for "3039" (av.=1.59) age group than for " $40-49$ " (av.=1.05) age group,

- Insanitary Areas was significantly more important for " $60+$ " (av.= -3.95) age group than for "18-29" $(\mathrm{av} .=-3.12)$ and "30-39" (av.= -3.28) age groups, 
- Waste disposal areas was significantly more important for "40-49" (av.= -3.89 ) age group than for "18-29" (av.=-3.46) age group,

- Treatment facilities was significantly more important for "40-49" (av.= -3.86) and "50-59" (av.= -3.70) age groups than for "18-29" (av.= 3.21) age group,

- Natural gas and tube filling facilities was significantly more important for "60+" (av.= -3.82), "50-59" (av.= -3.76) and "40-49" (av.= -3.84) age groups than for "18-29" (av.=-3.19) age group,

- Petrol stations was significantly more important for "60+" (av.= -3.31), "50-59" (av.= -3.15), "40-49" $(\mathrm{av} .=-3.26)$ and "30-39" (av.= -2.87$)$ age groups than for "18-29" (av.= -2.27) age group,

- Wireless towers was significantly more important for "60+" (av.= -3.84), "50-59" (av.= -3.63) and "40-49" (av.= -3.70) age groups than for "18-29" (av.=-3.04) age group,

- Energy transmission lines was significantly more important for "60+" (av.= -3.74), "50-59" (av.= 3.50 ) and "40-49" (av.= -3.65 ) age groups than for "18-29" (av.= -3.00) age group,

- Underdeveloped areas was significantly more important for " $40-49$ " (av.= -3.51) age group than for "18-29" (av.=-3.04) age group,

- Marsh areas was significantly more important for "60+" (av.= -4.07), "40-49" (av.= -3.89) and "3039 " (av.= -3.76) age groups than for "18-29" (av.= 3.34) age group,

- Natural disaster areas was significantly more important for "60+" (av.= -4.08) and "40-49" (av.= 4.00) age groups than for "18-29" (av.= -3.48) age group,

- Untreated stream sides was significantly more important for "60+" (av.= -3.77), "50-59" (av.= $3.55)$, "40-49" (av.= -3.70) and "30-39" (av.= -3.50) age groups than for "18-29" (av.=-3.06) age group,

- Worship Places was significantly more important for "60+" (av.=1.84) age group than for "18-29" (av.=2.92) and "30-39" (av.=1.59) age groups and additionally for "50-59" (av.=2.32) age group than for "18-29" (av.=2.92) age group,

- Education level was significantly more important for 40-49" (av.=3.65) and "50-59" (av.=3.73) age groups than for 18-29" (av.=3.18) age group,

- Neighbourliness relations was significantly more important for "40-49" (av.=3.74) and "60+" (av.=3.91) age groups than for "18-29" (av.=3.36) and "30-39" (av.=3.45) age groups,
- House owner/rent situation was significantly more important for "60+" (av.=2.58) and "50-59" (av.=2.49) age groups than for "30-39" (av.=2.00) age group,

- Climate condition was significantly more important for "50-59" (av.= -2.06) age group than for "18$29 "(\mathrm{av}=-1.23)$ age group,

- Air pollution was significantly more important for "50-59" (av.= -3.79) age group than for "18-29" (av. $=-3.25$ ) age group,

- Noise pollution was significantly more important for "60+" (av.= -3.83) and "50-59" (av.= -3.76) age groups than for "18-29" (av.=-3.22) age group.

In addition, no findings were obtained through Tamhane's method concerning Health-care Organizations, public/private hospitals, Educational Institutions, primary schools, high schools, courses, fire department/112 emergency, Attraction Centers, Shopping Centers, Cultural Centers, playgrounds, Transportation Networks, railway station, metro stations, bus stations, minibus lines, Cemeteries, Business Centers, View, lake, river, etc. view, a city view, crime level, Environmental Perspective, prestigious neighbourhoods, developmental potential and Underground, Ground, Over-Ground Features.

All in all, 82 criteria were tested through ANOVA. Based on the results of ANOVA, there were not significant differences in eight criteria, whereas differences were detected between the remaining groups through Bonferroni and Tamhane methods. Bonferroni method failed to find a significant difference between the age groups of 15 criteria, while there were significant differences between the age groups in 33 criteria, but there were not significant differences in 26 criteria.

\section{CONCLUSION AND SUGGESTIONS}

Real estates are of importance for all age groups. As one ages, they gain more importance. Comfort and ease stand out in old age in the process of meeting any need. Besides, for these age groups, who have given up their active business lives and have now a regular income, the balance of price/benefit must be properly analyzed. For instance, evaluation of buying or renting a house for shelter is only possible with a real valuation and an analysis of price/benefit. As we look into more details, we see that the relationship of valuation of real estates with economy and social sciences becomes stronger.

Table 3 The Criteria which age groups consider important

\begin{tabular}{|l|l|l|l|l|}
\hline \multicolumn{2}{|c|}{ ORDERED AGE GROUPS } \\
\hline “18-29” Age Group & \multicolumn{1}{|c|}{$\begin{array}{c}\text { “30-39” Age } \\
\text { Group }\end{array}$} & “40-49” Age Group & “50-59" Age Group & \multicolumn{1}{|c|}{ “60+ Age Group } \\
\hline $\begin{array}{l}\text { Cinema/theatre } \\
\text { Historical/touristic } \\
\text { places }\end{array}$ & $\begin{array}{l}\text { Courthouse } \\
\text { Airport }\end{array}$ & $\begin{array}{l}\text { Waste disposal areas } \\
\text { Underdeveloped Areas }\end{array}$ & $\begin{array}{l}\text { Climate condition } \\
\text { Air pollution }\end{array}$ & $\begin{array}{l}\text { Community clinic, health } \\
\text { center, etc. } \\
\text { Green Areas } \\
\text { Recreation areas } \\
\text { Parks } \\
\text { Insanitary Areas }\end{array}$ \\
\hline & & & & \\
\hline
\end{tabular}




\begin{tabular}{|c|c|c|c|c|}
\hline \multicolumn{2}{|l|}{$\begin{array}{l}\text { Entertainment Centers } \\
\text { Fair, concert area, etc. } \\
\text { Sport facilities } \\
\text { Stadium/hippodrome } \\
\text { Entertainment venues }\end{array}$} & \multicolumn{2}{|l|}{$\begin{array}{l}\text { Jailhouse } \\
\text { Treatment facilities } \\
\text { Education level }\end{array}$} & \\
\hline & & & \multicolumn{2}{|l|}{$\begin{array}{l}\text { Worship Places } \\
\text { House owner/rent situation } \\
\text { Noise pollution }\end{array}$} \\
\hline & & \multicolumn{3}{|c|}{$\begin{array}{l}\text { Natural gas and tube filling facilities } \\
\text { Wireless towers } \\
\text { Energy transmission lines }\end{array}$} \\
\hline & \multicolumn{4}{|c|}{$\begin{array}{l}\text { Petrol stations } \\
\text { Untreated stream sides }\end{array}$} \\
\hline \multicolumn{5}{|c|}{ UNORDERED AGE GROUPS } \\
\hline & & “30-39” Age Group & “40-49” Age Group & “60+” Age Group \\
\hline & & & \multicolumn{2}{|l|}{$\begin{array}{l}\text { Forest/copses } \\
\text { Natural disaster areas } \\
\text { Neighbourliness relations } \\
\end{array}$} \\
\hline & & \multicolumn{3}{|l|}{ Marsh areas } \\
\hline
\end{tabular}

In this study, we examined whether the importance of criteria varies with age groups and if it really does, which criteria actually change. It was seen that there were significant differences between young and old age groups. The "18-29" and "30-39" age groups classified as young generally enjoy being entertained and walking around. This is verified by the results of the analysis with more importance to entertainment centers. In addition, the interest taken by the "18-29" age group in cultural activities was demonstrated by the fact that they considered cultural centers important. It was seen that those in the "40-49" and "50-59" age groups considered the education level of the neighbourhood residents and proximity to jailhouse more important.

Community clinic, health center, etc. is of great importance for old and elderly people. This is confirmed in the analysis for the " $60+$ " age group. Besides, green areas is also important for the "60+" age group. Furthermore, people at the age of 50 and over want to lead their lives in a neighbourhood far from air pollution and noise, with neighbours as homeowners and close to worship places (Table 3).

It was observed that waste disposal areas, treatment facilities, natural gas and tube filling facilities, petrol stations, wireless towers, energy transmission lines, underdeveloped areas, marsh areas, natural disaster areas and untreated stream sides from insanitary areas were of negative importance to different age groups (Table 1.3). In other words, nearly all age groups want to be away from areas harmful to health. Therefore, these criteria have the effect of reducing the value of plot.

Since young people enjoy strolling, being entertained, doing sports, joining in cultural and social activities, they wish to have entertainment and cultural centers near the house they would reside in. As people get older, they want to have a community clinic they can reach readily when they become sick, a park where they can walk around when they are bored and a sanctuary where they can worship. It is seen that people demand a more serene, peaceful, healthier and more tranquil environment when they become old. Therefore, depending on the age group, related criteria come to the fore as regards the real estate in which they will reside.

\section{ACKNOWLEDGEMENTS}

The authors would like to thank interviewers who made efforts and respondents who patiently completed the survey in the data collection phase of the survey.

This study is supported by the Scientific and Technological Research Council of Turkey (TUBITAK) with 115 Y769 Projects Number.

\section{REFERENCES}

Açlar, A., Demir, H., \& Çağdaş, V., 2003. Taşınmaz değerleme uzmanlığı ve Jeodezi-Fotogrametri (Harita) Mühendisliği [Real estate valuation expert and GeodesyPhotogrammetri (Map) Engineering], HKM Jeodezi, Jeoinformasyon ve Arazi Yönetimi, 88, 15-20.

Altunışık, Remzi., Çoşkun, Recai., Bayraktaroğlu, Serkan., \& Yıldırım, Engin., 2010. Sosyal bilimlerde araştırma yöntemleri: SPSS uygulamalı [Research methods in social sciences: SPSS applied]. Sakarya: Sakarya Yayıncilık.

Bender, A., Din, A., Hoesli, M., \& Brocher, S., 2000. Environmental preferences of homeowners, further evidence using the AHP method. Journal of Property Investment \& Finance, 18(4), 445-55.

Bulut, B., Allahverdi, N., Kahramanlı, H., \& Yalpır, Ş., 2011. A SVR based approach on real-estate valuation, International Journal of Arts \& Sciences, 4(15), 323333.

Çakır, P., \& Sesli, A. F., 2013. Arsa vasıflı tașınmazların değerine etki eden faktörlerin ve bu faktörlerin önem sıralarının belirlenmesi [Determination of factors 
affecting the real-estate value of land property and the rank of importance of these factors]. Harita Teknolojileri Elektronik Dergisi, 5(3), 1-16.

Damigos, D., \& Anyfantis, F., 2011. The value of view through the eyes of real estate experts: A fuzzy delphi approach. Landscape and Urban Planning, 101, 171-78. doi: 10.1016/j.landurbplan.2011.02.009

Doğan, N., \& Doğan, ., 2014. Birinci tür hata'nın kontrolü ve adımsal (stepwise) çoklu karşılaştırma testleri [Control of type I error and stepwise multiple comparison tests]. Düzce Üniversitesi. Sağlık Bilimleri Enstitüsü Dergisi, 4(1), 28-33.

El-Gohary, M., 2004. Property valuation model effect of traffic noise on property value. ECE 557 Project, 1-4.

Gulnar, B., 2007. Araştırma görevlilerinin iş tatminini sağlama aracı olarak örgütsel iletişim ve iletişim doyumu: kamu ve özel üniversite karşılaştırması [Organizational communication and communication satisfaction as a means of job satisfaction for research assistants: A comparison between public and private universities]. Doktora tezi, Selçuk Üniversitesi, Sosyal Bilimler Enstitüsü, Halkla lişkiler ve Tanıtım A.B.D., Araştırma Yöntemleri Bilim Dalı, Konya.

Hammer, T.R., Coughlin, R.E., \& Horn IV., E.T., 1974. The effect of a large urban park on real estate value. Journal of the American Planning Association, 40(4), 274-77. doi: $10.1080 / 01944367408977479$

Henry, E.N.N., 2013. From turtle populations to property values: The effects of lakeshore residential development and the invasive zebra mussel. PhD diss., Michigan State University, Fisheries and Wildlife, Michigan.

Hurma, H., Kubaş, A., \& nan, .H., 2012. Emlak yönetiminde gayrimenkul değerlerine etki eden faktörlerin analizi. Namık Kemal Üniversitesi, Sosyal Bilimler Metinleri, 1, Tekirdağ.

IBM, 2015. One-Way ANOVA Post Hoc Tests, Available at: <http://www-01.ibm.com/support/ knowledgecenter/SSLVMB_23.0.0/spss/base/idh_onew_ post.dita>, [Accessed Date: October 25, 2015].

Jim, C.Y., \& Chen, W.Y., 2009. Value of Scenic Views: Hedonic Assessment of Private Housing in Hong Kong. Landscape and Urban Planning, 91, 226-34. doi: 10.1016/j.landurbplan.2009.01.009

Kayri, M., 2009. Araştırmalarda gruplar arası farkın belirlenmesine yönelik çoklu karşılaştırma (Post-Hoc) teknikleri [Multiple comparison (Post-Hoc) techniques for determining of the difference between groups in researches]. Fırat Üniversitesi. Sosyal Bilimler Dergisi, 19(1), 51-64.

Köktürk, E., 2009. Taşınmaz değerleme: Durum saptaması ve yönelimler [Real estate valuation: Situation detection and trends]. 12. Türkiye Harita Bilimsel ve Teknik Kurultayı, Paper presented at Twelfth Turkey
Map Scientific and Technical Conference, Ankara, May 11-15.

Kryvobokov, M., 2005. Estimating the weights of location attributes with the Analytic Hierarchy Process in Donetsk, Ukraine. Nordic Journal of Surveying and Real Estate Research, 2(2), 5-29.

Kuşan, H., Aytekin, O., \& Özdemir, ., 2010. The use of fuzzy logic in predicting house selling price. Expert Systems with Applications, 37, 1808-1813.

Lipscomb, C.A., Wang, Y., \& Kilpatrick, S.J., 2012. Unconventional shale gas development and real estate valuation issues. The Official Journal of the Southern Regional Science Association, 42, 161-75.

Mortgage Calculator, 2016. The History of American Mortgage, Available at:

$<$ http://www.mortgagecalculator.org/helpful-

advice/american-mortgage-history.php >, [Accessed Date: April 3, 2016].

Muehlenbachs, L., Spiller, E., \& Timmins, C., 2015. The housing market impacts of shale gas development. American Economic Review, 105(12), 3633-59.

Nişanc1, R., 2005. CBS ile nominal değerleme yöntemine dayalı piksel tabanlı kentsel taşınmaz değer haritalarının üretilmesi [The production of pixel based urban land value maps with nominal valuation method using GIS]. Doktora Tezi, Karadeniz Teknik Üniversitesi, Fen Bilimleri Enstitüsü, Jeodezi ve Fotogrametri Mühendisliği A.B.D., Trabzon.

OECD, 2015. Health Spending and Health at a Glance 2015, OECD Indicators, Available at: <https://data.oecd.org/healthres/health-spending.htm> and $\quad<$ http://www.oecd-ilibrary.org/social-issuesmigration-health/health-at-a-glance-2015/life-

expectancy-at-birth_health_glance-2015-6-en>,

[Accessed Date: March 8, 2016].

Psych Colorado, 2015. Multiple Comparison Procedures, Available at: $<$ http://psych.colorado.edu/ carey/

Courses/PSYC5741/handouts/Multiple_Comparison_Pr ocedures.pdf>, [Accessed Date: October 25, 2015].

Real Estate Tax Law, 1970. 1319 Numbered [1319 Sayılı Emlak Vergisi Kanunu], Yayımlandığ 1 Resmi Gazete Sayıs1 13576.

Ridker, R.G., \& Henning, J. A., 1967. The determinants of residential property values with special reference to air pollution, The Review of Economics and Statistics, 49(2), 246-57.

Selim, H., 2009. Determinants of house prices in Turkey: Hedonic regression versus artificial neural network. Expert Systems with Applications, 36, 28432852.

Szczepanska, A., Senetra, A., \& WasilewiczPszczołkowska, M., 2015. The effect of road traffic noise on the prices of residential property-A case study 
of The Polish City of Olsztyn. Transportation Research Part D, 36, 167-77.

Teker, S., Önden, ., \& Hekimoğlu, H., 2012. stanbul Finans Merkezi Projesi ve Bölgesindeki Emlak Fiyatlarına Etkisi, şletme Araştırmaları Dergisi, 4(4) 62-76.

TKGM, 2015. llere Göre Tapu statistik Bilgilerinin Dağılımı 2015, Available at <http://uygulamalar.tkgm.gov.tr/ybs/ybs/Tapuistatistik Arsiv/2015/Aralik/TapuIstatistik.htm>, [Accessed Date: July 13, 2016].

TUIK, 2015. llerin Nüfusu, Yıllık Artış Hızı ve Net Göç Hızı 2015, Available at: 〈http://www.tuik.gov.tr/UstMenu.do?metod=temelist>, [Accessed Date: July 13, 2016].

Turaman, C., 2001. Yaşlı sağlı̆̆g hizmetlerinin birinci basamakta planlanması [Planning elderly care at the basic level of health services]. Turkish Journal of Geriatrics, 4(1), 22-27.

UNECE WPLA 2001. Land (real estate) mass valuation systems for taxation purposes in Europe, Moscow: The Federal Land Cadastre Service of Russia, Available at: <http://www.unece.org/fileadmin/

DAM/hlm/documents/Publications/mass.valuation.pdf $>$, [Accessed Date: March 3, 2015].

UNECE WPLA 2014. Survey on land administration systems, Geneva: United Nations, Available at: <http://www.unece.org/fileadmin/DAM/hlm/documents/ Publications/survey.land.admin. [Accessed Date: March 3, 2015].

USPAP 2013. The uniform standards of professional appraisal practice, The United States of America: The Appraisal Foundation, Available at: $\langle$ http://www.appraisertom.com/USPAP-2014-15.pdf >, [Accessed Date: March 5, 2015].

Yalpir, S. 2007. Bulanık mantık metodolojisi ile taşınmaz değerleme modelinin geliştirilmesi ve uygulamasi: Konya örneği [The Development and application of a real-estate valuation model with fuzzy logic methodology: Konya case study]. Doktora Tezi, Selçuk Üniversitesi, Fen Bilimleri Enstitüsü, Jeodezi ve Fotogrametri Mühendisliği A.B.D., Konya.

Yalpir, S., Durduran, S.S., Unel F.B., \& Yolcu, M., 2014. Creating a valuation map in GIS through Artificial Neural Network Methodology: A case study. Acta Montanistica Slovaca, 19(2), 89-99.

Yomralığlu, T., 1993. A nominal asset value-based approach for land readjustment and its implementation using Geographical Information Systems. PhD diss., University of Newcastle upon Tyne, Department of Surveying, UK.

Yomralıŏlu, T., 1997. Taşınmazların değerlendirilmesi ve kat mülkiyeti mevzuatı [Assessment of real estate and legislation of condominium ownership]. Trabzon: JEFOD-Kentsel Alan Düzenlemelerinde mar Planı Uygulama Teknikleri.

YSK, 2015. 1/ lçe Seçmen ve Sandık Sayıları 2015, Available at:

<http://www.ysk.gov.tr/ysk/content/conn/YSKUCM/pat h/Contribution\%20Folders/ HaberDosya/2015MV-ililceSandikSayilari.pdf $>$, [Accessed Date: July 13, 2016].

Zheng, S., Cao, J., Kahn, M.E., \& Sun, C., 2014. Real estate valuation and cross-boundary air pollution externalities: Evidence from Chinese Cities. J Real Estate Finan Econ, 48, 398-414. doi: 10.1007/s11146013-9405-4

Zoning Law, 1985. 3194 Numbered [3194 Say1l mar Kanunu]. Yayımlandığı Resmi Gazete Sayısı: 18749.

Copyright (C) International Journal of Engineering and Geosciences (IJEG). All rights reserved, including the making of copies unless permission is obtained from the copyright proprietors. 